\title{
Abbreviated or Micro-Entity Accounts? Effect of Financial Reporting Format on the Availability of Trade Credit
}

\author{
Farah Saerens * and Stefanie Ceustermans \\ Department of Business, Vrije Universiteit Brussel (VUB), 1050 Brussels, Belgium; stefanie.ceustermans@vub.be \\ * Correspondence: farah.saerens@vub.be
}

Citation: Saerens, F.; Ceustermans, S. Abbreviated or Micro-Entity

Accounts? Effect of Financial Reporting Format on the Availability of Trade Credit. Sustainability 2021, 13, 8137. https://doi.org/10.3390/ su13158137

Academic Editors: Tensie Steijvers and Maarten Corten

Received: 21 May 2021

Accepted: 16 July 2021

Published: 21 July 2021

Publisher's Note: MDPI stays neutral with regard to jurisdictional claims in published maps and institutional affiliations.

Copyright: (c) 2021 by the authors. Licensee MDPI, Basel, Switzerland. This article is an open access article distributed under the terms and conditions of the Creative Commons Attribution (CC BY) license (https:// creativecommons.org/licenses/by/ $4.0 /)$.
Abstract: The purpose of this study was to investigate the association between the financial statement format (abbreviated or micro) and the level of trade credit. To test this relationship, we used a sample of 76,490 company-year observations of small companies in Belgium over the period of 2017-2019. We found that micro-entity accounts are negatively associated with the level of trade credit. Hence, our results provide evidence that more detailed financial statements are associated with higher levels of trade credit. In addition, we show that suppliers increase their reliance on the financial statement format when companies have lower inventory levels. Our results provide additional insights into the value of financial statements of small companies in the context of trade credit decisions. This study is set within the wider context of the simplification measures taken by the European Union (EU) to reduce the administrative burdens for small companies. The recent policy measures have further extended the debate on financial reporting regulation for small companies. A primary topic in this context is the discussion of the value of publicly available financial information in a small company context.

Keywords: micro-entities; financial reporting (format); abbreviated accounts; micro-entity accounts; trade credit

\section{Introduction}

This study is set within the wider context of the Europe 2020 Strategy for smart, sustainable, and inclusive growth, which aims to reduce administrative burdens and improve the business environment, particularly for small companies. One of the most burdensome constraints for SMEs is compliance with administrative regulations. SMEs are believed to suffer disproportionately from such burdens due to their limited resources [1]. Financial reporting and auditing have been identified as key areas for reducing the administrative burden for European companies. Hence, Europe introduced a new Accounting Directive (2013/34/EU) that permits Member States of the EU to exempt 'micro-entities' (microentities are companies that do not exceed the thresholds of at least two of the following three criteria at the balance sheet date: (i) a balance sheet total of EUR 350,000, (ii) a net turnover of EUR 700,000, and (iii) an average workforce during the financial year of 10 employees) from the general financial statement publication requirement (the balance sheet information should, however, be duly filed, in accordance with national law, with at least one designated competent authority, and the information should be forwarded to the business register, so a copy should be obtainable upon application). As a result, micro-entities will experience a substantial reduction in financial disclosure requirements. According to EUROSTAT, micro-entities represent $93 \%$ of all companies in the European Union (the EU28). They also contribute the largest shares of both value added and employment, at $20.8 \%$ and $29.7 \%$, respectively. Together with small companies, they are considered 'the backbone of the EU economy'.

The recent policy measures have further extended the debate on financial reporting regulation for small companies. A primary topic in this context is the discussion of the value of publicly available financial information in a small company context. The arguments 
presented for relaxing financial reporting requirements of small companies are based on the premise that the benefits of financial statements are relatively small because of the limited number of financial statement users (COM/2007/0394 final). There are also costs associated with financial reporting requirements, which are said to disproportionally affect small firms to a greater extent. There are direct costs from collecting and producing financial information but also, and maybe more importantly, indirect costs resulting from disclosing information to the public and, in particular, to competitors [2-4]. Financial statements often contain confidential information, and small companies in particular may perceive the disclosure of this information as a breach of privacy $[1,3,5]$.

Although the cost and benefits arising from financial disclosure may differ between small and large companies, Collis [6] and Kitching et al. [1] have criticized this one-sided conception of regulation as a business burden. These authors call for a more nuanced approach, where the potential benefits from publicly available information are also taken into account when simplifying financial reporting requirements for small companies. Financial disclosure may reduce information asymmetries between small companies and their stakeholders, which might improve access to finance [1]. This may be particularly relevant in the context where stakeholders, such as small trading partners, lack the power to demand additional information from the company.

There are relatively few studies available that provide theoretical grounds or empirical evidence on the costs and benefits of financial disclosure by small companies. Research on this subject is nevertheless important to help understand the value of publicly available financial information in a small company setting. Several authors have therefore called for more empirical research in this area (see, for example, $[1,6,7])$. To the best of our knowledge, there is only one study based on a large sample that has examined the relationship between reduced financial disclosure under the small/micro-company reporting regimes and corporate outcomes. A recent study by Peel [7] showed that UK companies that opt for micro-entity accounts were allocated lower credit scores by a credit rating agency. Because the credit scorer is aware that the typical small company files abbreviated accounts under the small company regime, the choice for micro-entity accounts acts as a negative signal of lower quality (higher risk). In this paper, we aim to contribute to this growing area of research by examining the association between the financial statement format (abbreviated or micro accounts) and the level of trade credit. This research is important given that small companies struggle more than large companies to obtain finance (see, e.g., [8]).

Prior research has shown that more detailed or qualitative financial statements can reduce information asymmetries in small companies and, hence, improve access to bank finance (see, e.g., [9-14]). Few studies have paid attention to the role of financial statements in access to trade credit. Nevertheless, trade credit has been shown to be an important source of short-term finance for private companies (see, e.g., [15-18]).

To test the relationship, we used a sample of 76,490 company-year observations of micro-entities in Belgium over the period of 2017-2019. We found that micro-entity accounts are negatively associated with the level of trade credit. In addition, we found evidence that suppliers increase their reliance on the financial statement format when companies have lower inventory levels. Our results provide additional insights into the value of financial statements of small companies in the context of trade credit decisions.

The remainder of the paper is organized as follows. In Section 2, we review prior literature and the development of our hypotheses. In Section 3, the institution setting in Belgium is discussed. Section 4 presents our sample selection and research methodology. The results are presented and discussed in Section 5. Finally, we summarize our conclusions in Section 6.

\section{Literature Review and Hypotheses Development}

\subsection{Motives and Importance of Trade Credit}

There are two main motives for the use of trade credit: the 'transactions' motive and the 'financing' motive. 
To fully explain the transactions motive, we compare two situations: the transaction of goods with or without the interference of trade credit. If an exchange of goods happens without the interference of the trade credit mechanism, there will be no time gap between the payment of goods and the delivery of these goods. In other words, when the goods are delivered, the payment needs to occur immediately to conclude the transaction. A company always needs to hold a financial buffer to cover for the inconsistent fluctuations of the exchange of goods. Keeping this cash buffer also implies additional costs. This is not optimal for the operation of a company and brings about a lot of uncertainty in money holdings and flows [19].

If we include the instrument of trade credit in this situation, the transaction of goods can be split into two separate transactions: goods for a short-term loan and the shortterm loan for money. By making certain agreements through a contract, there is more certainty about the payments and the timing of these payments. In this way, the uncertainty regarding money flows and money holding can be reduced. When the buyer and supplier exchange information, the frequency of payments can be optimized. Since a buyer now has more knowledge on the amount of cash the company will need in the short-term future, money flows will be optimized. The exchange cost will also be lowered because of the separation between the delivery of goods and the payment for these goods [19]. The mechanism of trade credit serves to reduce transaction uncertainty [20] and transaction costs [21-23].

The other motive for the use of trade credit is a 'financial' motive. Suppliers of trade credit often give cash discounts to their buyers to stimulate early payments of goods and services. The interest rates on these cash discounts are higher than the rates for other external funds [21,22]. The 'financing' theory offers an explanation as to why firms would prefer 'more expensive' trade credit over finance from financial institutions. In short, credit from financial institutions is limited and harder to obtain for small opaque companies. Because of their inherent lack of transparency, information asymmetries are typically very large in small companies [24]. Hence, it is usually more difficult for banks to distinguish between high and low creditworthy firms. This uncertainty and the difficulty of obtaining credible financial information on small companies constitute the reason why banks charge higher interest rates and limit their access of finance [21]. The next form of finance, according to the 'pecking order' theory, is trade credit, which is considered to be a substitute for missing or expensive short-term credit from banks. Furthermore, trade credit is easy to access and ready at hand.

Prior research has shown the importance of trade credit as a short-term source of finance for small companies. More specifically, small firms that are credit rationed by banks seem to use more trade credit [22,25-28]. Studies in various countries have examined the use of trade credit in SMEs. Petersen and Rajan [22] showed, based on data on small and private US companies, that trade credit is used as a substitute for unavailable bank loans. Huyghebaert [26] focused on Belgian start-ups and provided additional evidence that start-ups use more trade credit when financial constraints are large.

García-Teruel and Martínez-Solano [29] used a comprehensive, pan-European database with financial data on seven European countries (including Belgium) for the period of 1996 to 2002. They found that continental European countries (France, Belgium, Greece, and Spain) exhibit relatively high levels of trade credit to total assets (ranging from $24.9 \%$ for Spain to $28.5 \%$ for France). Moreover, they also found evidence that firms turn to suppliers for credit when alternative sources of finance are limited. Similarly, a more recent study on European SMEs found that trade credit is greater in volume than short-term bank credit. Trade credit represents on average $22.5 \%$ of total assets compared with $9.4 \%$ of short-term bank credit. The study also confirmed the substitution effect.

Overall, by virtue of its size, we can conclude that trade credit is an important form of financing for SMEs. 


\subsection{Hypothesis Development}

In general, financial statements mitigate the problem of information asymmetry that arises from the separation of ownership and control. However, micro-entities are typically closely held, and shareholders take an active role in managing the company $[6,30]$. In addition, they usually have direct access to management accounts. Therefore, the typical agency relationship that exists in large companies with respect to the separation of ownership and control is seldom the case in micro-entities. Accordingly, prior studies questioned whether financial statements are useful in a small private company setting (see, e.g., [30-32]).

However, micro-entities still engage in contracting with external parties, such as banks, suppliers, and customers, for whom financial information is also important (see, e.g., [33-36]). Financial statements ensure that a minimum of financial information is available to interested users. Small companies rely more on debt and trade credit in comparison with large companies [37]. Consequently, in small companies, agency conflicts are likely to occur between the small company and capital providers, such as banks and suppliers. Although agency conflicts can be reduced via private channels $[31,37,38]$, that does not mean that financial statements are not valuable in lending decisions. This is especially true for micro-entities, who typically have fewer competing information sources available, given the lack of business analysts, press releases, and non-accounting information. In this respect, the financial statements are usually the only source of verifiable financial information available $[39,40]$.

Indeed, previous research has shown that more detailed or qualitative financial information can reduce information asymmetries of small companies, which may improve their access to finance. Most of these studies focus on access to bank lending (see, e.g., [9-14]). However, trade credit is also widely used as a source of finance by small companies [41]. This is especially the case when bank lending is limited or is not available [22,27]. The question of whether more detailed financial information can improve access to trade credit has received much less attention. Information asymmetries may lead to credit rationing by financial institutions; however, it may equally affect supplier trade credit. This may be particularly relevant in the context where small trading partners lack the power to demand additional financial information from the company [33].

Collis et al. [41] conducted interviews in order to provide empirical evidence on the value of financial statements of SMEs in obtaining trade credit. Their results demonstrate that lenders use information derived from SMEs' financial statements together with other (nonfinancial) information. Financial statement information becomes more important when larger entities contract with smaller entities. García-Teruel et al. [16] show that larger Spanish SMEs with more qualitative financial statements have access to more trade credit. Similarly, Elemes and Filip [42] find evidence that high-quality financial reporting is associated with more trade credit financing for European private companies. Ceustermans et al. [43] find that voluntary disclosure in the financial statements of small Belgian companies increases the level of trade credit. These studies provide evidence that suppliers use (directly or indirectly) financial statements to assess customers' credit risk.

Other studies, however, suggest that more detailed or qualitative financial statements are negatively associated with the availability of trade credit. Suppliers have several advantages in overcoming information asymmetries because of the personal relationship they have with their customers and their ability to liquidate assets [22,44]. As such, financial statement information is considered less important to evaluate a customer's creditworthiness. In addition, and consistent with the pecking order of debt financing, companies prefer bank lending and only turn to more expensive trade credit when bank lending is not available $[40,45]$. Therefore, small companies with more qualitative or more detailed financial statements have easier access to bank lending (see, e.g., $[9,13,14])$. The opposite is true for more financially opaque firms and, as a consequence, their demand for trade credit is likely higher [40,44]. In their study on listed US companies, Chen et al. [44] found evidence that accounting quality is negatively associated with the use of trade credit. This provides evidence that suppliers have advantages in overcoming information 
asymmetries and are therefore more likely to provide trade credit to customers with low accounting quality, thus suggesting that they are more financially opaque.

Although there are conflicting arguments and findings, previous studies conducted in a small or private company context $[7,16,42,43]$ showed that financial reporting choices that increase financial reporting quality or transparency have positive economic consequences. To our knowledge, the study of Peel [7] was the first study to examine the new category of micro-entities, which are allowed to publish reduced financial statement information in micro-entity accounts. Based on a sample of 13,102 young, small, and micro companies in the United Kingdom, the results show that, relative to small companies filing abbreviated accounts, companies filing micro accounts are associated with lower credit scores. The author argued that filing micro-entity accounts conveys a negative signal to the credit scorer that micro companies are of lower quality (higher risk), because they publish less detailed financial statements compared with small companies. Relatedly, Collis [6] found that small UK companies often file audited and full financial statements voluntarily to send positive signals to lenders, suppliers, and customers that the business is well managed. A recent survey report of The European Federation of Accountants and Auditors for smalland medium-sized enterprises (EFAA for SMEs) documented that one of the reasons that micro-entities do not file micro-entity accounts is because of expectations of banks and trading partners and because micro-entities want to maintain transparency and signal 'good quality' reporting.

Building on the prior studies reviewed above, we posit that suppliers may perceive the filing of micro-entity accounts as a negative signal about the quality of the company. Hence, we hypothesize the following:

Hypothesis 1. There is a negative association between filing micro-entity accounts and the level of trade credit.

Chen et al. [44] found in their study of listed US firms that accounting quality is less important for suppliers in assessing customer credit risk for customers with lower inventory liquidation costs. The authors argued that, in the case of lower inventory liquidation costs, suppliers can repossess the supplied inventory and recover their claims. Similarly, we posit that inventory may also change the importance of the format of the financial statements. Whether a micro-entity files abbreviated or micro-entity accounts may be less relevant when customers' inventory levels are higher. Conversely, the format of the financial statements becomes more important when inventory levels are lower, because in the case of default, there is less to recover. Hence, suppliers will have to rely more on financial information to assess customers' credit risk in the case of lower inventory levels. Hence, we expect that suppliers will be more willing to supply trade credit to customers with micro-entity accounts when inventory levels are higher (and thus inventory liquidation costs are lower). Therefore, we predict that the effect of filing micro-entity accounts on the reliance of trade credit is weaker for companies with higher levels of inventory. Based on the above discussion, we develop the second hypothesis:

Hypothesis 2. The association between filing micro-entity accounts and trade credit is weaker for companies with higher inventory levels.

Suppliers use a customer's reputation and relationships to reduce uncertainty and concerns about credit risk [22,46,47]. Young, growing companies typically lack such a proven track record or have not had the chance to build ongoing relationships with their suppliers. In the situation where relationships and track records are missing, the financial statements may be one of the few information sources available to assess credit risk or to decide whether or not to extend trade credit. With regard to private companies, Elemes and Filip [42] found that the relation between financial reporting quality and trade credit is stronger for younger firms. The authors argued that suppliers complement insider 'information-asymmetry-mitigating mechanisms' with financial reporting quality in the 
trade credit decision, in particular when information asymmetries are higher. As companies grow older, more information becomes available. Hence, we expect that suppliers attach less importance to the financial statement format when customers are older and already have an established track record or relationship. We propose the following hypothesis:

Hypothesis 3. The association between filing micro-entity accounts and trade credit is weaker for older companies.

\section{Institutional Setting in Belgium}

All Belgian companies with limited liability must prepare and file their financial statements according to a specific format, layout, and content. By using this standardized financial reporting format, users can more easily compare financial statements of different companies. There are three financial statement formats, depending on the size of the company. Table 1 depicts the financial statement formats and the size criteria. The qualification is satisfied if at least two of the three criteria are met.

Table 1. Belgian Size Criteria.

\begin{tabular}{|c|c|c|c|}
\hline $\begin{array}{c}\text { Financial Reporting } \\
\text { Format }\end{array}$ & $\begin{array}{c}\text { Annual Average } \\
\text { Number of Employees }\end{array}$ & $\begin{array}{l}\text { Annual Turnover } \\
\text { (Excluding VAT) }\end{array}$ & $\begin{array}{c}\text { Balance Sheet } \\
\text { Total }\end{array}$ \\
\hline Full accounts & $\begin{array}{l}>>50 \\
(>100: \text { full accounts, } \\
\text { regardless other criteria) }\end{array}$ & $\begin{array}{l}\text { >EUR } 9 \text { million } \\
\text { (previously: EUR } \\
7.3 \text { million) }\end{array}$ & $\begin{array}{c}\text { >EUR } 4.5 \text { million } \\
\text { (previously: EUR } \\
3.65 \text { million) }\end{array}$ \\
\hline Abbreviated accounts & $<50$ & $\begin{array}{c}<\text { EUR } 9 \text { million } \\
\text { (previously: EUR } \\
7.3 \text { million) }\end{array}$ & $\begin{array}{c}<\text { EUR } 4.5 \text { million } \\
\text { (previously: EUR } \\
3.65 \text { million) }\end{array}$ \\
\hline Micro-entity accounts & $<10$ & $\begin{array}{c}<\text { EUR 700,000 } \\
\text { (previously not } \\
\text { defined) }\end{array}$ & $\begin{array}{c}<\text { EUR 350,000 } \\
\text { (previously not } \\
\text { defined) }\end{array}$ \\
\hline
\end{tabular}

The New Accounting Directive gave the Member States the opportunity to choose for maximum simplification for the micro-entities. Based on the preference of the Member State, the micro-entities could receive exemptions on four key points:

1. An exemption from drawing up notes to the financial statements.

2. An exemption from some accruals.

3. An exemption from preparing an annual report.

4. An exemption from publishing the annual financial information [48].

Unlike most Member States, the Belgian legislator foresees more extensive requirements than the ones foreseen in the EU directives and has not gone far in the option for simplification [49]. Belgian micro-entities still have to prepare and publish their financial statements with the Central Balance Sheet Office. In addition, both micro-entities and small companies are allowed to use the same abbreviated balance sheet and profit-and-loss account layouts. The difference between the micro-entity accounts and the abbreviated accounts is that the explanatory notes to the financial statements are very limited for the micro-entity accounts [49].

\section{Research Design}

\subsection{Sample Selection}

We obtained data from a proprietary private database (this extensive dataset is collected by Companyweb, a company that specializes in collecting company information in Belgium. For the purposes of this study, Companyweb granted us confidential access to its data. The received dataset contains information on all financial statements of all limited liability companies in Belgium) consisting of 3,390,051 firm-year observations. This database includes financial information on Belgian private companies for the period 
between 2010 and 2020. Companies who operate in the financial sector (Nacebel code 64-68) were excluded from our selection because they have to report according to different requirements. Thereafter, we excluded all the missing values from our database, resulting in a sample of 3,341,363 observations. The sample selection only includes small private companies that file either abbreviated or micro-entity accounts. In this way, we excluded all large companies due to the fact that large companies are not allowed to file an abbreviated format or micro-entity accounts of their financial statements. Next, we used two selection criteria to retain micro-entities only: (1) a balance sheet total of not more than EUR 350,000 and (2) an average workforce during the financial year of a maximum of 10 FTEs (note that in Belgium, small companies and micro-entities are allowed to prepare and publish abbreviated or micro-entity financial statements and, in these formats, they have the possibility to not disclose sales and the cost of sales. The vast majority of small and micro-entities make use of this option and, hence, for many small and micro-entities, the sales figure is not available). Subsequently, we selected the years 2017, 2018, and 2019, since micro-entity accounts were only implemented in 2016 (2013/34/EU). This process yielded a sample of 153,655 observations (52,298 for 2017; 52,737 for 2018; and 48,620 for 2019). Table 2 provides a breakdown of the data selection.

Table 2. Data breakdown.

\begin{tabular}{lcc}
\hline \multicolumn{1}{c}{ Criteria } & Drop & Sample \\
\hline Belgian private firms & $-48,688$ & $3,390,051$ \\
Missing values & $-221,636$ & $3,341,363$ \\
Firms disclosing the full format & $-1,937,257$ & $3,119,727$ \\
Only year 2017, 2018, and 2019 & $-1,182,470$ & $1,182,470$ \\
Micro-entities only & $-77,165$ & 153,655 \\
PSM & & 76,490 \\
Final sample & & \\
\hline
\end{tabular}

\subsection{Matching Procedure}

Endogeneity concerns could arise in this particular research into the relation between the financial statement format and trade credit. To mitigate the concerns that companies filing micro-entity accounts differ inherently from companies filing abbreviated accounts, we used a propensity-score-matching (PSM) process to construct a control sample. Propensity score matching is a statistical matching technique that alleviates endogeneity problems and ensures unbiased estimates. However, both of these problems stem from the same cause, namely functional form misspecification (FFM). FFM occurs when the model fails to explain the relationship between the outcome variable and the explanatory variables (i.e., the relationship is mis-specified) [50].

PSM assembles a new dataset by matching a company that files abbreviated accounts to a company that files micro-entity accounts with the same company characteristics with the closest propensity score. We opted for a one-to-one match without replacement with the minimum caliper to ensure optimal matches. This led to a loss of 77,165 observations, which gave us a final data sample of 76,490 (i.e., 38,245 matches). We used the following logistic model in Equation (1) to estimate the probability of filing micro-entity accounts for a company's financial statements on the basis of prior financial reporting studies in private companies (e.g., $[6,13,34])$, where the indices $i$ and $t$ refer to company and time, respectively:

$$
\begin{gathered}
\text { MICRO }_{\mathrm{i}, \mathrm{t}}=\alpha_{0}+\beta_{1} \text { SIZE }_{\mathrm{i}, \mathrm{t}}+\beta_{2} \mathrm{AGE}_{\mathrm{i}, \mathrm{t}}+\beta_{3} \text { PROFIT }_{\mathrm{i}, \mathrm{t}}+\beta_{4} \text { INTANGIBLES }_{\mathrm{i}, \mathrm{t}} \\
+\beta_{5} \text { ALTMAN }_{\mathrm{i}, \mathrm{t}}+\beta_{6-8} \text { YEAR }_{\mathrm{i}, \mathrm{t}}+\varepsilon
\end{gathered}
$$


The dependent variable in Equation (1), MICRO, is a dummy variable that takes a value of 1 if the firm filed its financial statements using micro-entity accounts and 0 if the abbreviated format of the financial statements was filed. The explanatory variables are defined as follows: SIZE is the natural logarithm of total assets; AGE is measured as the natural logarithm of the number of years since incorporation of the company; PROFIT is the ratio of operating income to total assets; INTANGIBLES is measured as the ratio of intangible assets to total assets; and ALTMAN is the output of a Z-score model (i.e., credit strength test) that predicts a firm's likelihood of bankruptcy, specifically developed for private firms [51]. This model is an accounting-based version of the Z-score models that does not rely on market data. The data include the years 2017, 2018, and 2019. All variables, except for YEAR and the dummy variable MICRO, were winsorized by $1 \%$.

Hence, a match was found for 38,245 company-year observations from companies who filed their financial statements using micro-entity accounts between 2017 and 2019, resulting in a matched sample of 76,490 company-year observations. It is crucial to evaluate the quality of the matched sample afterwards, considering that PSM is an aggregate measurement [50]. We assessed the quality by checking if the company characteristics of the treatment group (i.e., companies who file their financial statements using micro-entity accounts) and the control group (i.e., companies who file an abbreviated form of their financial statements) do not show significant differences. Table 3, which represents the descriptive statistics of our PSM sample, shows that the company characteristics of our treatment group are equal to those of the control group. A $t$-test was also performed to estimate the treatment effect. All of this indicated good matching (the overall $\chi^{2}$ balance test was significant; $\left.\chi^{2}(5)=7987.281 ; p<0.001\right)$.

Table 3. Descriptive statistics for the PSM sample.

\begin{tabular}{|c|c|c|c|c|c|c|c|}
\hline \multirow[b]{2}{*}{ Variable } & \multicolumn{3}{|c|}{$\begin{array}{c}\text { (1) Micro-Entity Accounts } \\
\text { Sample } \\
(N=38,245)\end{array}$} & \multicolumn{3}{|c|}{$\begin{array}{c}\text { (2) Abbreviated Accounts } \\
\text { Sample } \\
(N=38,245)\end{array}$} & \multirow[b]{2}{*}{$\begin{array}{l}t \text {-Test } \\
\text { (1)-(2) }\end{array}$} \\
\hline & Mean & SD & Median & Mean & SD & Median & \\
\hline SIZE & 11.090 & 0.780 & 11.216 & 11.789 & 0.833 & 12.011 & -112.411 \\
\hline AGE & 1.960 & 0.902 & 2.012 & 2.372 & 0.879 & 2.477 & -64.093 \\
\hline PROFIT & 0.105 & 0.291 & 0.100 & -0.043 & 0.401 & 0.024 & 58.061 \\
\hline INTANGIBLES & 0.032 & 0.103 & 0 & 0.028 & 0.095 & 0 & 4.965 \\
\hline ALTMAN & 0.432 & 0.189 & 0.401 & 0.514 & 0.213 & 0.464 & -56.538 \\
\hline
\end{tabular}

SIZE = Natural logarithm of total assets at year $t$; AGE $=$ The natural logarithm of the number of years since incorporation; PROFIT $=$ Operating income to total assets at year $t$; INTANGIBLES $=$ Intangible assets to total assets at year $t$; ALTMAN = Output of a Z-score model (i.e., credit strength test) that predicts a firm's likelihood of bankruptcy.

\subsection{Estimation Model}

To examine the relationship between the format of the financial statements and trade credit, we propose the following linear regression model in Equation (2), where the indices $\mathrm{i}$ and $\mathrm{t}$ refer to the company and time, respectively:

$$
\begin{gathered}
\text { ACCOUNTS_PAYABLE }_{i, t}=\alpha_{0}+\beta_{1} \text { MICRO }_{i, \mathrm{t}}+\beta_{2} \text { MICRO }_{\mathrm{i}, \mathrm{t}} * \text { INVENTORY }_{\mathrm{i}, \mathrm{t}} \\
+\beta_{3} \text { MICRO }_{\mathrm{i}, \mathrm{t}} * \text { AGE }_{\mathrm{i}, \mathrm{t}}+\beta_{4} \text { SIZE }_{\mathrm{i}, \mathrm{t}}+\beta_{5} \text { PROFIT }_{\mathrm{i}, \mathrm{t}}+\beta_{6} \text { AGE }_{\mathrm{i}, \mathrm{t}}+\beta_{7} \text { SOLVENCY }_{\mathrm{i}, \mathrm{t}} \\
+\beta_{8} \text { LIQUIDITY Y }_{\mathrm{i}, \mathrm{t}}+\beta_{9} \text { TLOANS }_{\mathrm{i}, \mathrm{t}}+\beta_{10} \text { INTANGIBLES }_{\mathrm{i}, \mathrm{t}}+\beta_{11} \text { INVENTORY }_{\mathrm{i}, \mathrm{t}} \\
+\beta_{12} \text { ACC_RECEIVABLE }_{\mathrm{i}, \mathrm{t}}+\beta_{13} \text { TANG_FIXED_ASSETS }_{\mathrm{i}, \mathrm{t}}+\beta_{14} \text { NACE }_{\mathrm{i}, \mathrm{t}} \\
+\beta_{15-17} \text { YEAR }_{\mathrm{i}, \mathrm{t}}+\varepsilon
\end{gathered}
$$

Variable labels and definitions are reported in Table 4. The dependent variable in this research is ACCOUNTS_PAYABLE, measured as accounts payable to total assets, based on previous trade credit studies $[22,43,44]$. The main explanatory variable in our 
regression analysis is MICRO, which is a dummy variable coded as 1 if a company filed micro-entity accounts and 0 if the abbreviated format of the financial statements was filed. We hypothesize a negative coefficient for the test variable MICRO.

Table 4. Variable labels and definitions.

\begin{tabular}{ll}
\hline Label & Definition \\
\hline $\begin{array}{l}\text { Dependent variable } \\
\text { ACCOUNTS_PAYABLE }\end{array}$ & Ratio of accounts payable to total assets at year $t$ \\
MICRO & $\begin{array}{l}\text { Dummy variable that takes a value of } 1 \text { if the firm } \\
\text { filed its FS using micro-entity accounts and } 0 \text { if a } \\
\text { company files abbreviated accounts }\end{array}$ \\
Control variables & Natural logarithm of total assets at year $t$ \\
SIZE & Operating income to total assets at year $t$ \\
PROFIT & $\begin{array}{l}\text { Natural logarithm of the number of years since } \\
\text { incorporation }\end{array}$ \\
AGE & $\begin{array}{l}\text { Equity divided by total assets at year } t \\
\text { Current assets to current liabilities at year } t\end{array}$ \\
SOLVENCY & Short- and long-term debt with financial institutions \\
LIQUIDITY & to total assets at year $t$ \\
TLOANS & Intangible assets to total assets at year $t$ \\
INTANGIBLES & Inventory to total assets at year $t$ \\
INVENTORY & Accounts receivable to total assets at year $t$ \\
ACC_RECEIV & Tangible fixed assets to total assets at year $t$ \\
TANG_FIXED_ASSETS &
\end{tabular}

To test Hypothesis 2, we interacted MICRO with INVENTORY. We expected a positive coefficient for the interaction term MICRO*INVENTORY. To test Hypothesis 3, we included the interaction variable MICRO*AGE, where AGE is measured as the natural logarithm of the numbers of years since incorporation of the company. We also expected a positive coefficient for this interaction variable. Subsequently, we included several control variables. SIZE is measured as the natural logarithm of total assets [22,52,53]. The variable PROFIT is measured as operating income to total assets. The variable AGE is measured as the natural logarithm of the number of years since incorporation. SOLVENCY is measured as equity divided by total assets, and LIQUIDITY as current assets to current liabilities. The variable TLOANS contains short- and long-term debt with financial institutions (i.e., heavily relying on bank lending). According to the aforementioned finance theory, we expect a negative coefficient for TLOANS, because more reliance on bank debt would imply less need for trade credit [28]. Next, TANG_FIXED_ASSETS is measured as tangible fixed assets to total assets and INTANGIBLES as intangible assets to total assets. The variable INVENTORY represents the inventory level and is measured as inventory to total assets. Finally, the variable ACC_RECEIV is measured as accounts receivable to total assets. In all of our models, we include year and industry fixed effects by adding year and industry dummy variables.

\section{Results and Discussion}

\subsection{Descriptive Statistics}

The descriptive statistics of the variables used for the linear regression are shown in Table 5. The mean of the dependent variable ACCOUNTS PAYABLE is 0.215 , which is in line with previous studies $[26,43,54]$. The fact that micro-entities are included in our sample must be taken into account; this is also reflected in the average of the variable SIZE. The total assets of the companies in the sample amount to EUR 93,339 on average (SIZE is calculated as the natural logarithm of total assets, which is 11.444 on average). 
Table 5. Descriptive statistics.

\begin{tabular}{lccccc}
\hline \multicolumn{1}{c}{ Variables } & Mean & SD & Median & Min & Max \\
\hline ACCOUNTS_PAYABLE & 0.215 & 0.260 & 0.130 & 0 & 1.577 \\
MICRO & 0.500 & 0.500 & 0.500 & 0.000 & 1.000 \\
SIZE & 11.444 & 0.881 & 11.533 & 7.847 & 12.766 \\
PROFIT & 0.031 & 0.358 & 0.055 & -2.057 & 0.713 \\
AGE & 2.166 & 0.914 & 2.303 & 0.000 & 4.007 \\
SOLVENCY & 0.098 & 1.166 & 0.333 & -7.929 & 0.948 \\
LIQUIDITY & 2.426 & 6.500 & 1.375 & 0.000 & 146.610 \\
TLOANS & 0.125 & 0.205 & 0.009 & 0.000 & 1.256 \\
INTANGIBLES & 0.030 & 0.099 & 0.000 & 0.000 & 0.557 \\
INVENTORY & 0.100 & 0.172 & 0.010 & 0.000 & 0.793 \\
ACC_RECEIV & 0.218 & 0.235 & 0.137 & 0.000 & 0.902 \\
TANG_FIXED_ASSETS & 0.238 & 0.230 & 0.167 & 0.000 & 0.902
\end{tabular}

Note: $N=76,490$. ACCOUNTS_PAYABLE = Ratio of accounts payable to total assets at year $t$; MICRO = Dummy:

1 if the firm filed its FS using micro-entity accounts and 0 if a company files abbreviated accounts; SIZE = Natural logarithm of total assets at year $t$; PROFIT = Operating income to total assets at year $t$; AGE = Natural logarithm of the number of years since incorporation; SOLVENCY = Equity divided by total assets at year $t$; LIQUIDITY $=$ Current assets to current liabilities at year $t$; TLOANS $=$ Short- and long-term debt with financial institutions to total assets at year $t$; INTANGIBLES = Intangible assets to total assets at year $t$; INVENTORY = Inventory to total assets at year $t$; ACC_RECEIV = Accounts receivable to total assets at year $t$; TANG_FIXED_ASSETS $=$ Tangible fixed assets to total assets at year $t$.

Furthermore, the operating income of our companies to total assets is 0.031 on average (PROFIT). The companies in the sample are on average 9 years old (the variable AGE is defined as the natural logarithm of the number of years since incorporation, which is 2.166 on average). The average of the variable SOLVENCY amounts to 0.098 . The variables LIQUIDITY, TLOANS, INTANGIBLES, INVENTORY, and ACC_RECEIV have an average of $2.426,0.125,0.030,0.100$, and 0.218 , respectively. Lastly, the mean of TANG_FIXED_ASSETS amounts to 0.238 .

Table 6 presents all the correlations between all the variables used for the analysis. As expected, we observed a negative correlation between the dummy variable MICRO and the dependent variable ACC_PAYABLE $(-0.105, p<0.01)$. This indicates that microentities have less trade credit. All other Pearson correlations were as expected. All control variables also correlated significantly with ACC_PAYABLE. The variables INVENTORY and ACC_RECEIV correlated positively with the dependent variable. All other control variables correlated negatively with ACC_PAYABLE. To ensure no multicollinearity problems could arise in the regression analysis, variance inflation factor (VIF) values were checked. Generally, a threshold of below 5 gives a positive indication of the absence of multicollinearity [55]. Table 3 shows all the low-variance inflation factor levels, which were well below 5 . All the variables, except for YEAR and the dummy variable MICRO, were winsorized by $1 \%$. This means that the outliers were reduced to a $98 \%$ interval to mitigate the impact of extreme cases.

\subsection{Linear Regression}

Table 7 presents the outcome of the linear regression analysis with the matched sample of 76,490 company-year observations. Model 1 represents the baseline model with control variables only. Model 2 reports the OLS regression results for testing the association between MICRO and the level of trade credit for Hypothesis 1. Models 3 and 4 introduce the interaction variables MICRO*INVENTORY and MICRO*AGE in order to test our second and third hypotheses. The adjusted $\mathrm{R}^{2}$ for model 1 is $24.3 \%$, and the adjusted $\mathrm{R}^{2}$ for models 2, 3, and 4 is $24.6 \%$ (note that the $\mathrm{R}^{2}$ is the same across models 2,3 , and 4 . This indicates that including the interaction variables in models 3 and 4 does not increase the overall explanatory power of our models). All control variables are significant and have the predicted coefficient sign. The variables INTANGIBLES, INVENTORY, and ACC_RECEIV have a positive coefficient, as stated in prior literature. All other control variables (SIZE, PROFIT, AGE, SOLVENCY, LIQUIDITY, TLOANS, and TANG_FIXED_ASSETS) have a 
negative coefficient, which is also in line with previous literature. Consistent with H1, the coefficient of MICRO was negative and highly significant (model 2). The results provide evidence that companies who file micro-entity accounts have less trade credit than companies who file abbreviated accounts. Model 3 of Table 7 provides the results of testing Hypothesis 2. The coefficient on MICRO remained negative and statistically significant. The coefficient on the interaction term, MICRO*INVENTORY, was positive but statistically significant only at the $10 \%$ level. This suggests that the effect of filing microentity accounts on trade credit is less pronounced in companies with higher inventory levels. This result provides support for our argument $(\mathrm{H} 2)$ that suppliers are more willing to supply trade credit to companies filing micro-entity accounts when inventory levels are high. Model 4 of Table 7 further shows the results of testing Hypothesis 3. We found a positive, though insignificant, coefficient for the interaction term MICRO*AGE. Hence, our results provide no evidence regarding the moderating role of age. In sum, we found evidence that suppliers increase their reliance on the financial statement format when companies have lower inventory levels.

\subsection{Supplementary Analysis}

As described above, a concern in examining the impact of the financial statement format on trade credit is that the choice to switch from an abbreviated to a micro-entity financial statement format is subject to endogeneity and self-selection. In order to conduct further tests of the association between the financial statement format and the level of trade credit, we also looked at data before (i.e., 2013-2015) and after (i.e., 2016-2019) the implementation of the new Accounting Directive in 2016. As reported in Table 8, companies that switched their financial statement format from abbreviated to micro-entity accounts (i.e., switchers) differ in terms of several observable characteristics from companies that did not switch from an abbreviated to a micro-entity format (i.e., non-switchers). Examining the data pre-implementation, we found that switchers have on average a higher firm performance than that of non-switchers (i.e., switchers have a lower Altman score, are more profitable, and have higher solvability). Switchers also have on average more financial debt and less trade debt when compared with those of non-switchers. 
Table 6. Pearson correlation matrix.

\begin{tabular}{|c|c|c|c|c|c|c|c|c|c|c|c|c|c|}
\hline & Acc_Payable & Micro & Size & Profit & Age & Solvency & Liquidity & Tloans & Intangibles & Inventory & $\begin{array}{c}\text { Acc } \\
\text { Receiv }\end{array}$ & $\begin{array}{c}\text { Tang_Fixed } \\
\text { _Assets }\end{array}$ & VIF \\
\hline ACC_PAYABLE & 1 & & & & & & & & & & & & \\
\hline MICRO & $-0.105^{* *}$ & 1 & & & & & & & & & & & 1.444 \\
\hline SIZE & $-0.182 * *$ & $-0.402 * *$ & 1 & & & & & & & & & & 1.609 \\
\hline PROFIT & $-0.299 * *$ & $0.205^{* *}$ & $0.225^{* *}$ & 1 & & & & & & & & & 1.356 \\
\hline AGE & $-0.054 * *$ & $-0.226 * *$ & 0.123 ** & $0.018^{* *}$ & 1 & & & & & & & & 1.112 \\
\hline SOLVENCY & $-0.495^{* *}$ & $0.087^{* *}$ & $0.374^{* *}$ & $0.447^{* *}$ & $-0.014 * *$ & 1 & & & & & & & 1.566 \\
\hline LIQUIDITY & $-0.161^{* *}$ & $0.019^{* *}$ & $0.048^{* *}$ & $0.043 * *$ & $0.088^{* *}$ & $0.152 * *$ & 1 & & & & & & 1.074 \\
\hline TLOANS & $-0.009 * *$ & $-0.126^{* *}$ & $0.090^{* *}$ & $-0.125^{* *}$ & 0.001 & $-0.239 * *$ & $-0.090 * *$ & 1 & & & & & 1.290 \\
\hline INTANGIBLES & $-0.038^{* *}$ & $0.018^{* *}$ & $0.041^{* *}$ & $-0.042 * *$ & $-0.169 * *$ & -0.011 ** & $-0.054^{* *}$ & $0.116^{* *}$ & 1 & & & & 1.146 \\
\hline INVENTORY & $0.139 * *$ & -0.076 ** & 0.025 ** & $-0.055^{* *}$ & $0.093 * *$ & $-0.055^{* *}$ & $-0.038^{* *}$ & $0.027 * *$ & $-0.067 * *$ & 1 & & & 1.181 \\
\hline ACC_RECEIV & $0.170 * *$ & $-0.044^{* *}$ & $0.047^{* *}$ & 0.002 & $-0.043 * *$ & $-0.024^{* *}$ & -0.050 ** & $-0.092 * *$ & $-0.127^{* *}$ & -0.218 ** & 1 & & 1.352 \\
\hline TANG_FIXED_ASSETS & $-0.106^{* *}$ & $-0.071^{* *}$ & 0.022 ** & $-0.067^{* *}$ & -0.002 & $-0.052 * *$ & $-0.127^{* *}$ & $0.344^{* *}$ & $-0.091 * *$ & -0.141 ** & $-0.343 * *$ & 1 & 1.493 \\
\hline
\end{tabular}

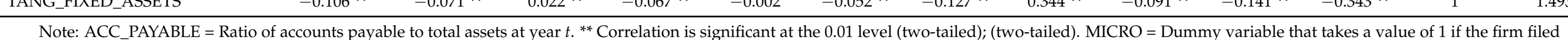

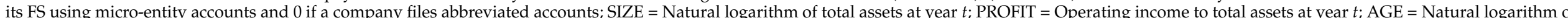

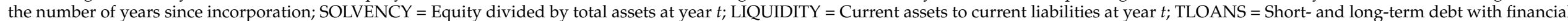

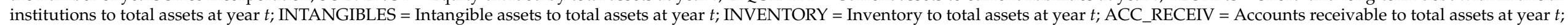

TANG_FIXED_ASSETS = Tangible fixed assets to total assets at year $t$.

Table 7. Linear regression results.

\begin{tabular}{|c|c|c|c|c|c|c|c|c|c|}
\hline \multicolumn{10}{|c|}{ Dependent Variable $=$ ACC_PAYABLE } \\
\hline \multirow[b]{2}{*}{ Variable } & \multirow[b]{2}{*}{ Expected Sign } & \multicolumn{2}{|c|}{ Model 1} & \multicolumn{2}{|c|}{ Model 2} & \multicolumn{2}{|c|}{ Model 3} & \multicolumn{2}{|c|}{ Model 4} \\
\hline & & $\beta$ & $t$-Value & $\beta$ & $t$-Value & $\beta$ & $t$-Value & $\beta$ & $t$-Value \\
\hline Constant & & 0.630 & 0.328 & $-0.047^{* * *}$ & -0.74 & $-0.048^{* * *}$ & -0.75 & $-0.047 * * *$ & -0.74 \\
\hline MICRO & - & - & & $-0.022 * * *$ & -9.80 & $-0.024 * * *$ & -9.61 & $-0.023^{* * *}$ & -4.54 \\
\hline MICRO*INV & + & - & & - & & $0.020 *$ & 1.65 & - & \\
\hline MICRO*AGE & + & - & & - & & - & & 0.000 & 0.17 \\
\hline SIZE & - & 0.008 & 8.392 & $0.019^{* * *}$ & 12.40 & $0.019^{* * *}$ & 12.48 & $0.019^{* * *}$ & 12.36 \\
\hline PROFIT & - & -0.075 & -30.968 & $-0.054^{* * *}$ & -18.62 & $-0.054^{* * *}$ & -18.63 & $-0.054^{* * *}$ & -18.62 \\
\hline AGE & - & -0.018 & -21.233 & $-0.011^{* * *}$ & -9.62 & $-0.011^{* * *}$ & -9.64 & $-0.011^{* * *}$ & -6.63 \\
\hline SOLVENCY & - & -0.103 & -126.000 & $0.027^{* * *}$ & 24.00 & $0.027 * * *$ & 23.98 & $0.027^{* * *}$ & 24 \\
\hline LIQUIDITY & - & -0.003 & -27.850 & $0.000 *$ & 1.69 & $0.000 *$ & 1.69 & $0.000 *$ & 1.69 \\
\hline TLOANS & - & -0.148 & -34.748 & $0.089^{* * *}$ & 12.31 & $0.089^{* * *}$ & 12.35 & $0.089 * * *$ & 12.3 \\
\hline INTANGIBLES & + & -0.068 & -8.190 & $-0.107^{* * *}$ & -11.45 & $-0.107^{* * *}$ & -11.47 & $-0.107^{* * *}$ & -11.45 \\
\hline
\end{tabular}


Table 7. Cont

\begin{tabular}{|c|c|c|c|c|c|c|c|c|c|}
\hline \multicolumn{10}{|c|}{ Dependent Variable $=$ ACC_PAYABLE } \\
\hline \multirow[b]{2}{*}{ Variable } & \multirow[b]{2}{*}{ Expected Sign } & \multicolumn{2}{|c|}{ Model 1} & \multicolumn{2}{|c|}{ Model 2} & \multicolumn{2}{|c|}{ Model 3} & \multicolumn{2}{|c|}{ Model 4} \\
\hline & & $\beta$ & $t$-Value & $\beta$ & $t$-Value & $\beta$ & $t$-Value & $\beta$ & $t$-Value \\
\hline INVENTORY & + & 0.208 & 42.939 & $0.093^{* * *}$ & 11.88 & $0.084^{* * *}$ & 8.48 & $0.093^{* * *}$ & 11.88 \\
\hline ACC_RECEIV & + & 0.169 & 44.612 & $0.144^{* * *}$ & 26.23 & $0.144^{* * *}$ & 26.19 & $0.144^{* * *}$ & 26.23 \\
\hline TANG_FIXED_ASSETS & - & -0.044 & -10.823 & $-0.094^{* * *}$ & -18.96 & $-0.094 * * *$ & -19.01 & $-0.094^{* * *}$ & -18.95 \\
\hline Year fixed effects & & Included & & Included & & Included & & Included & \\
\hline Industry effects & & Included & & Included & & Included & & Included & \\
\hline Number of observations & & 76,490 & & 76,490 & & 76,490 & & 76,490 & \\
\hline Adjusted $\mathrm{R}^{2}$ & & 0.243 & & 0.246 & & 0.246 & & 0.246 & \\
\hline F-statistic & & 3055.771 & & $63,745.034$ & & $63,845.034$ & & $63,845.034$ & \\
\hline$p$-value & & 0 & & 0.000 & & 0.000 & & 0.000 & \\
\hline
\end{tabular}

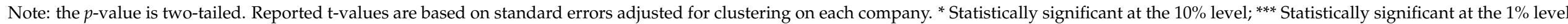

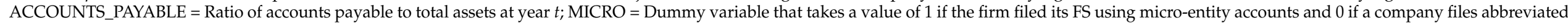

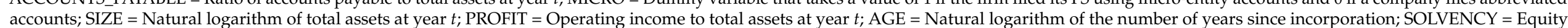

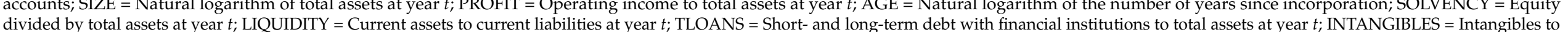
total assets at year $t$; INVENTORY = Inventory to total assets at year $t$; ACC_RECEIV = Accounts receivable to total assets at year $t$; TANG_FIXED_ASSETS $=$ Tangible fixed assets to total assets at year $t$ 
Table 8. Additional analysis: means and $t$-tests.

\begin{tabular}{|c|c|c|c|c|c|c|c|c|c|}
\hline \multicolumn{4}{|c|}{$\begin{array}{l}\text { Total Sample } \\
(n=1,456,955)\end{array}$} & \multicolumn{3}{|c|}{$\begin{array}{l}\text { Pre-Implementation } \\
\quad(n=569,234)\end{array}$} & \multicolumn{3}{|c|}{$\begin{array}{l}\text { Post-Implementation } \\
\quad(n=887,721)\end{array}$} \\
\hline Variable & Switchers & $\begin{array}{c}\text { Non- } \\
\text { Switchers }\end{array}$ & $t$-Test & Switchers & $\begin{array}{c}\text { Non- } \\
\text { Switchers }\end{array}$ & $t$-Test & Switchers & $\begin{array}{c}\text { Non- } \\
\text { Switchers }\end{array}$ & $t$-Test \\
\hline AGE & 2.249 & 2.279 & $-15.992 * * *$ & 2.234 & 2.227 & $2.549 * * *$ & 2.258 & 2.318 & $-23.734^{* * *}$ \\
\hline INTANGIBLES & 0.022 & 0.020 & $9.504^{* * *}$ & 0.025 & 0.022 & $8.582 * * *$ & 0.021 & 0.019 & $6.217 * * *$ \\
\hline ACC_RECEIV & 0.174 & 0.186 & $-26.897^{* * *}$ & 0.171 & 0.188 & $-22.985^{* * *}$ & 0.175 & 0.185 & $-16.116^{* * *}$ \\
\hline LIQUIDITY & 4.697 & 5.247 & $-16.623^{* * *}$ & 4.262 & 4.762 & $-10.364^{* * *}$ & 4.967 & 5.610 & $-14.307^{* * *}$ \\
\hline TANG_FIXED_ASSETS & 0.298 & 0.288 & $14.266^{* * *}$ & 0.317 & 0.299 & $17.382 * * *$ & 0.286 & 0.280 & $6.491^{* * *}$ \\
\hline SIZE & 11.337 & 11.355 & $-7.305^{* * *}$ & 11.354 & 11.345 & $2.315^{* * *}$ & 11.327 & 11.362 & $-11.019 * * *$ \\
\hline SOLVABILITY & -0.455 & -0.775 & $27.049 * * *$ & -0.384 & -0.746 & $20.813^{* * *}$ & -0.499 & -0.796 & $18.607^{* * *}$ \\
\hline TLOANS & 0.162 & 0.153 & $15.075^{* * *}$ & 0.174 & 0.160 & $14.465^{* * *}$ & 0.154 & 0.147 & 9.176 \\
\hline ACC_PAYABLE & 0.212 & 0.247 & $-63.205^{* * *}$ & 0.207 & 0.246 & $-46.884^{* * *}$ & 0.216 & 0.248 & $-44.032^{* * *}$ \\
\hline INVENTORY & 0.076 & 0.084 & $-22.828^{* * *}$ & 0.078 & 0.087 & $-14.706^{* * *}$ & 0.074 & 0.082 & $-16.712^{* * *}$ \\
\hline ALTMAN & 0.485 & 0.504 & $-38.930 * * *$ & 0.486 & 0.506 & $-26.769 * * *$ & 0.484 & 0.503 & $-28.225 * * *$ \\
\hline PROFIT & -0.010 & -0.044 & $38.672 * * *$ & -0.006 & -0.043 & $27.824^{* * *}$ & -0.013 & -0.045 & $27.689 * * *$ \\
\hline
\end{tabular}

*** Statistically significant at the $1 \%$ level. ACCOUNTS_PAYABLE $=$ Ratio of accounts payable to total assets at year $t$; SIZE $=$ Natural logarithm of total assets at year $t$; PROFIT $=$ Operating income to total assets at year $t$; AGE $=$ Natural logarithm of the number of years since incorporation; SOLVENCY $=$ Equity divided by total assets at year $t$; LIQUIDITY $=$ Current assets to current liabilities at year $t$; TLOANS = Short- and long-term debt with financial institutions to total assets at year $t$; INTANGIBLES $=$ Intangible assets to total assets at year $t$; INVENTORY $=$ Inventory to total assets at year $t$; ACC_RECEIV $=$ Accounts receivable to total assets at year $t$; ALTMAN $=$ Output of a Z-score model (i.e., credit strength test) that predicts a firm's likelihood of bankruptcy; TANG_FIXED_ASSETS = Tangible fixed assets to total assets at year $t$.

As a further test, we restricted our sample to companies that switched to micro-entity accounts only (i.e., the switchers). Hence, the analysis compared the level of trade credit before and after the implementation of the micro-entity regime, which was implemented in 2016. We estimate the model in Equation (3):

$$
\begin{aligned}
& \text { ACCOUNTS_PAYABLE }_{i, t}=\alpha_{0}+\beta_{1} \text { POST }_{i, t}+\beta_{2} \text { POST }_{i, t} * \text { INVENTORY }_{i, t} \\
& +\beta_{3} \text { POST }_{i, t} * \text { AGE }_{i, t}+\beta_{4} \text { SIZE }_{i, t}+\beta_{5} \text { PROFIT }_{i, t}+\beta_{6} \text { AGE }_{i, t}+\beta_{7} \text { SOLVENCY }_{i, t} \\
& +\beta_{8} \text { LIQUIDITY Y }_{i, t}+\beta_{9} \text { TLOANS }_{i, t}+\beta_{10} \text { INTANGIBLES }_{i, t}+\beta_{11} \text { INVENTORY Y }_{i, t} \\
& +\beta_{12} \text { ACC_RECEIVABLE }_{i, t}+\beta_{13} \text { TANG_FIXED_ASSETS }_{i, t}+\beta_{14} \text { NACE }_{i, t}++\varepsilon
\end{aligned}
$$

where POST is a dummy variable taking a value of 0 for observations before (i.e., 2013-2015) and 1 for observations after (i.e., 2016-2019) the regulatory change to take into account the switch from abbreviated to micro-entity accounts. We also included the interaction between the POST dummy and the two moderators from the main analyses INVENTORY and AGE (i.e., POST*INVENTORY and POST*AGE). We employed a sample of 283,660 micro-entities that switched from abbreviated to micro-entity accounts over the period of 2013-2019. The results of the additional regression are presented in Table 9. In contrast to our main analysis, the coefficient of the main variable POST was significant in model 1 but showed a positive sign. This implies that micro-entities that switched from abbreviated to micro-entity accounts have a higher level of trade credit after the implementation of the new Accounting Directive. One potential explanation for the positive coefficient is that micro-entities that switched from abbreviated to micro-entity accounts were already confident enough to make the switch to micro-entity accounts, given their relatively better financial performance (see Table 8). 
Table 9. Additional regression results.

\begin{tabular}{|c|c|c|c|c|c|c|c|}
\hline \multicolumn{8}{|c|}{ Dependent Variable $=$ ACC_PAYABLE } \\
\hline \multirow[b]{2}{*}{ Variable } & \multirow[b]{2}{*}{ Expected Sign } & \multicolumn{2}{|c|}{ Model 1} & \multicolumn{2}{|c|}{ Model 2} & \multicolumn{2}{|c|}{ Model 3} \\
\hline & & $\beta$ & $t$-Value & $\beta$ & $t$-Value & $\beta$ & $t$-Value \\
\hline Constant & & $0.363^{* * *}$ & 137.627 & $0.363^{* * *}$ & 137.510 & $0.359^{* * *}$ & 133.341 \\
\hline POST & - & $0.003 * * *$ & 3.73 & $0.002^{* *}$ & 1.99 & 0.002 & 9.074 \\
\hline$P^{\prime} O S T^{*} I N V$ & - & - & & $0.011^{* *}$ & 2 & - & \\
\hline$P_{O S T}^{*} A G E$ & - & - & & - & & 0.000 & -8.792 \\
\hline SIZE & - & $-0.011^{* * *}$ & -8.38 & $-0.011^{* * *}$ & -8.38 & $-0.011^{* * *}$ & -8.38 \\
\hline PROFIT & - & $-0.144^{* * *}$ & -42.27 & $-0.145^{* * *}$ & -42.28 & $-0.144^{* * *}$ & -42.28 \\
\hline$A G E$ & - & $-0.01^{* * *}$ & -18.64 & $-0.015^{* * *}$ & -18.64 & $-0.005^{* * *}$ & -18.64 \\
\hline SOLVENCY & - & $-0.020 * * *$ & 1.07 & $-0.020 * * *$ & -3.47 & $-0.020^{* * *}$ & -3.47 \\
\hline LIQUIDITY & - & $-0.005^{* * *}$ & -23.87 & $-0.005^{* * *}$ & -23.87 & $-0.005^{* * *}$ & -23.87 \\
\hline TLOANS & - & $-0.099 * * *$ & -58.22 & $-0.099 * * *$ & -58.22 & $-0.099 * * *$ & -58.22 \\
\hline INTANGIBLES & - & $-0.014^{* * *}$ & -7.68 & $-0.014^{* * *}$ & -5.88 & $-0.013^{* * *}$ & -5.73 \\
\hline INVENTORY & + & $0.176^{* * *}$ & 30.90 & $0.179 * * *$ & 28.08 & $0.184^{* * *}$ & 30.91 \\
\hline ACC_RECEIV & + & $0.246^{* * *}$ & 60.1 & $0.246^{* * *}$ & 60.84 & $0.258^{* * *}$ & 60.09 \\
\hline TANG_FIXED_ASSETS & - & $-0.029 * * *$ & -8.37 & $-0.029 * * *$ & -8.38 & $-0.029 * * *$ & -8.37 \\
\hline Industry effects & & Included & & Included & & Included & \\
\hline $\begin{array}{l}\text { Number of } \\
\text { observations }\end{array}$ & & 283,660 & & 283,660 & & 283,660 & \\
\hline Adjusted $R^{2}$ & & $32.2 \%$ & & $32.2 \%$ & & $32.2 \%$ & \\
\hline$F$-statistic & & $75,879,709$ & & $75,979,709$ & & $76,079,709$ & \\
\hline$p$-value & & 0 & & 0.000 & & 0.000 & \\
\hline
\end{tabular}

Note: The $p$-value is two-tailed. Reported $t$-values are based on standard errors adjusted for clustering on each company. ${ }^{* *}$ Statistically significant at the $5 \%$ level; ${ }^{* * *}$ Statistically significant at the $1 \%$ level. ACCOUNTS_PAYABLE $=$ Ratio of accounts payable to total assets at year $t$; POST $=$ Dummy variable that takes a value of 1 for the year of implementation and the post-implementation period (i.e., 2016-2019) and 0 if 2015; SIZE = Natural logarithm of total assets at year $t$; PROFIT $=$ Operating income to total assets at year $t$; AGE = Natural logarithm of the number of years since incorporation; SOLVENCY = Equity divided by total assets at year $t$; LIQUIDITY $=$ Current assets to current liabilities at year $t$; TLOANS $=$ Short- and long-term debt with financial institutions to total assets at year $t$; INTANGIBLES $=$ Intangibles to total assets at year $t$; INVENTORY $=$ Inventory to total assets at year $t$; ACC_RECEIV $=$ Accounts receivable to total assets at year $t$; TANG_FIXED_ASSETS $=$ Tangible fixed assets to total assets at year $t$.

Next, model 2 presents the results for the interaction term POST*INVENTORY. First, the significantly positive coefficient of INVENTORY indicates that the effect of inventory on trade credit is positive and significant in the pre-implementation period. The coefficient of the interaction term POST*INVENTORY was positive and significant at the 0.05 level. This suggests that the effect of filing micro-entity accounts (in the post-implementation period) on trade credit is less pronounced when inventory levels are high. Consistent with our prior findings, the coefficient of the interaction term POST*AGE was statistically insignificant. Hence, we found no support for the moderating role of age.

\section{Concluding Remarks}

In this study, we investigated the relationship between the financial statement format and the availability of trade credit on a broad sample of Belgian micro-entities. More specifically, we examined whether small companies that publish micro-entity accounts obtain less trade credit than companies that file abbreviated accounts. Consistent with the literature demonstrating that less detailed financial statement information is associated with a lower level of trade credit [16,42,43], our results show that filing micro-entity accounts is associated with less trade credit. This contrasts with the results of Chen et al. [44], who found that accounting quality is negatively associated with the use of trade credit in US listed companies. In addition, we found that the effect of filing micro-entity accounts, relative to filing abbreviated accounts, is weaker for companies with higher inventory levels. Contrary to expectations, no support was found for the hypothesis regarding the moderating role of age.

This study contributes to the literature in two ways. First, our study focuses on the smallest companies, i.e., the new category of micro-entities. Besides the study of Peel [7], 
no research to date has explored the financial reporting choices of micro-entities. Given their economic significance, it is important to gain more detailed insight into the value of financial reporting for these smallest companies. Second, our research complements and extends the literature on corporate outcomes of financial reporting choices of small companies by focusing on trade credit. Prior research tended to look at bank debts only. However, trade credit has also been shown to be an important source of short-term finance for small private companies [15].

The evidence from this study is of relevance to micro-entities, their stakeholders, and regulators, as it offers additional insight into the value of publicly available information in a small company context. From a regulator's perspective, our results suggest that relaxing financial reporting requirements for the smallest companies may potentially result in unintended negative consequences $[1,6]$. In addition, owner-managers of small and micro-entities are often not fully aware of the consequences of their filing choices. It seems therefore important that in the process of reducing administrative burdens for the smallest companies, more qualitative and quantitative research is needed to provide evidence in order to guide policy-makers in their actions to reduce administrative burdens of SMEs.

Our study suffers from a number of limitations. First, it should be noted that evidence generated from archival data mainly suggests association, not causation. It is, for example, possible that suppliers demand abbreviated accounts instead of micro-entity accounts to extend trade credit. Furthermore, in the supplementary analysis, we compared the group of micro-entities that switched from abbreviated to micro-entity accounts before and after the new Accounting Directive. We found that micro-entity accounts are associated with higher levels of trade credit after the implementation of the Accounting Directive. These results may give rise to the idea that other mechanisms might be at play. For example, we found that switchers have on average better financial health than that of companies that did not make the switch to micro-entity accounts. Hence, switchers may, for example, have different financing needs or were already able to develop their reputations. Related to the above, we lack information on how financial statement information is used by suppliers and, hence, how it may influence lending decisions. A further research extension of the current study would be to examine how the financial statements are actually used by creditors and what the impact is of customer-supplier relationships compared to financial information. As such, more qualitative research may help to increase our understanding of the role of financial statements in trade credit decisions. We also focus exclusively on trade credit. While we controlled for bank credit in our analysis, further research in this area could therefore also take into account the impact of bank credit on the relationship between trade credit and financial reporting filing decisions. Lastly, although a rich dataset was used, it should be noted that this is a single-country study. Further research could verify the results of this study in other jurisdictions to provide further evidence on the association between the financial statement format and corporate outcomes.

Author Contributions: Conceptualization, S.C.; methodology, F.S. and S.C.; software, F.S. and S.C.; validation, F.S. and S.C.; formal analysis, F.S. and S.C.; investigation, F.S. and S.C.; resources, S.C.; data curation, F.S. and S.C.; writing-original draft preparation F.S. and S.C.; writing-review and editing, S.C.; visualization, F.S. and S.C.; supervision, S.C. All authors have read and agreed to the published version of the manuscript.

Funding: This research received no external funding.

Institutional Review Board Statement: Not applicable.

Informed Consent Statement: Not applicable.

Data Availability Statement: The data that support the findings of this study are available from the corresponding author upon reasonable request.

Acknowledgments: We thank the anonymous reviewers and Marie-Laure Vandenhaute, whose comments helped improve and clarify this manuscript. 
Conflicts of Interest: The authors declare no conflict of interest.

\section{References}

1. Kitching, J.; Kašperová, E.; Collis, J. The contradictory consequences of regulation: The influence of filing abbreviated accounts on UK small company performance. Int. Small Bus. J. 2015, 33, 671-688. [CrossRef]

2. Collis, J.; Dugdale, D.; Jarvis, R. Deregulation of small company financial reporting in the UK. In Contemporary Issues in Accounting Regulation; Springer: Boston, MA, USA, 2001; pp. 167-185.

3. Eierle, B. Filing practice of small and medium-sized companies: Empirical findings from Austria. Int. Small Bus. J. 2008, 26, 491-528. [CrossRef]

4. Roberts, C.; Sian, S. Accounting and Financial Reporting Guidance for Small Enterprises: A case study of the UK. In Proceedings of the Emerging Issues in International Accounting and Business Conference, Padua, Italy, 20-22 July 2006; pp. 779-800.

5. The European Federation of Accountants and Auditors for Small- and Medium-Sized Enterprises (EFAA for SMEs). EFAA Survey. Acceptance of the Micro-Entities Accounting Option in Europe. 2019. Available online: www.efaa.com/publications/ accountants-instrumental-to-micro-entities-simplifying-their-accounting/ (accessed on 29 April 2021).

6. Collis, J. Determinants of voluntary audit and voluntary full accounts in micro-and non-micro small companies in the UK. Account. Bus. Res. 2012, 42, 441-468. [CrossRef]

7. Peel, M.J. The impact of filing micro-entity accounts and the disclosure of reporting accountants on credit scores: An exploratory study. Account. Bus. Res. 2019, 49, 648-681. [CrossRef]

8. Wang, X.; Han, L.; Huang, X. Bank competition, concentration and EU SME cost of debt. Int. Rev. Financ. Anal. 2020, 71, 101534. [CrossRef]

9. De Meyere, M.; Vander Bauwhede, H.; Van Cauwenberge, P. The impact of financial reporting quality on debt maturity: The case of private firms. Account. Bus. Res. 2018, 48, 759-781. [CrossRef]

10. Kim, J.B.; Simunic, D.A.; Stein, M.T.; Yi, C.H. Voluntary audits and the cost of debt capital for privately held firms: Korean evidence. Contemp. Account. Res. 2011, 28, 585-615. [CrossRef]

11. Moro, A.; Fink, M.; Maresch, D. Reduction in information asymmetry and credit access for small and mediumsized enterprises. $J$. Financ. Res. 2015, 38, 121-143. [CrossRef]

12. Paananen, M.; Renders, A.; Blomkvist, M. Causes and consequences of improvements in the information environment for Swedish small and mid-sized firms. Account. Eur. 2016, 13, 21-42. [CrossRef]

13. Van Caneghem, T.; Van Campenhout, G. Quantity and quality of information and SME financial structure. Small Bus. Econ. 2012, 39, 341-358. [CrossRef]

14. Vander Bauwhede, H.; De Meyere, M.; Van Cauwenberge, P. Financial reporting quality and the cost of debt of SMEs. Small Bus. Econ. 2015, 45, 149-164. [CrossRef]

15. Berger, A.N.; Udell, G.F. A more complete conceptual framework for SME finance. J. Bank. Financ. 2006, 30, 2945-2966. [CrossRef]

16. García-Teruel, P.J.; Martínez-Solano, P.; Sánchez-Ballesta, J.P. Supplier financing and earnings quality. J. Bus. Financ. Account. 2014, 41, 1193-1211. [CrossRef]

17. Huang, L.; Ying, Q.; Yang, S.; Hassan, H. Trade Credit Financing and Sustainable Growth of Firms: Empirical Evidence from China. Sustainability 2019, 11, 1032. [CrossRef]

18. Psillaki, M.; Daskalakis, N. Are the determinants of capital structure country or firm specific? Small Bus. Econ. 2009, 33, 319-333. [CrossRef]

19. Seifert, D.; Seifert, R.W.; Protopappa-Sieke, M. A review of trade credit literature: Opportunities for research in operations. Eur. J. Oper. Res. 2013, 231, 245-256. [CrossRef]

20. Ferris, J.S. A transactions theory of trade credit use. Q. J. Econ. 1981, 96, 243-270. [CrossRef]

21. Elliehausen, G.E.; Wolken, J.D. The demand for trade credit: An investigation of motives for trade credit use by small businesses. Fed. Res. Bull. 1993, 79, 929.

22. Petersen, M.A.; Rajan, R.G. Trade credit: Theories and evidence. Rev. Financ. Stud. 1997, 10, 661-691. [CrossRef]

23. Summers, B.; Wilson, N. Trade credit and customer relationships. Manag. Decis. Econ. 2003, 24, 439-455. [CrossRef]

24. Berger, A.N.; Udell, G.F. Small business credit availability and relationship lending: The importance of bank organisational structure. Econ. J. 2002, 112, F32-F53. [CrossRef]

25. Carbo-Valverde, S.; Rodriguez-Fernandez, F.; Udell, G.F. Trade credit, the financial crisis, and SME access to finance. J. Money Credit Bank. 2016, 48, 113-143. [CrossRef]

26. Huyghebaert, N. On the Determinants and dynamics of trade credit use: Empirical evidence from business Start-ups. J. Bus. Financ. Account. 2006, 33, 305-328. [CrossRef]

27. McGuinness, G.; Hogan, T. Bank credit and trade credit: Evidence from SMEs over the financial crisis. Int. Small Bus. J. 2016, 34, 412-445. [CrossRef]

28. Ogawa, K.; Sterken, E.; Tokutsu, I. The trade credit channel revisited: Evidence from micro data of Japanese small firms. Small Bus. Econ. 2013, 40, 101-118. [CrossRef]

29. García-Teruel, P.J.; Martinez-Solano, P. Determinants of trade credit: A comparative study of European SMEs. Int. Small Bus. J. 2010, 28, 215-233. [CrossRef] 
30. Ball, R.; Shivakumar, L. Earnings quality in UK private firms: Comparative loss recognition timeliness. J. Account. Econ. 2005, 39, 83-128. [CrossRef]

31. Burgstahler, D.C.; Hail, L.; Leuz, C. The importance of reporting incentives: Earnings management in European private and public firms. Account. Rev. 2006, 81, 983-1016. [CrossRef]

32. Bharath, S.T.; Sunder, J.; Sunder, S.V. Accounting quality and debt contracting. Account. Rev. 2008, 83, 1-28. [CrossRef]

33. Arrunada, B. Mandatory accounting disclosure by small private companies. Eur. J. Law Econ. 2011, 32, 377-413. [CrossRef]

34. Kitching, J.; Kasperova, E.; Blackburn, R.; Collis, J. Small Company Abbreviated Accounts: A Regulatory Burden or a Vital Disclosure? The Institute of Chartered Accountants of Scotland (ICAS): Edinburgh, UK, 2011.

35. Cole, V.; Branson, J.; Breesch, D. The uniformity-flexibility dilemma when comparing financial statements. Int. J. Account. Inf. Manag. 2012, 20, 114-141. [CrossRef]

36. Hope, O.K.; Vyas, D. Private company finance and financial reporting. Account. Bus. Res. 2017, 47, 506-537. [CrossRef]

37. Berger, A.N.; Udell, G.F. The economics of small business finance: The roles of private equity and debt markets in the financial growth cycle. J. Bank. Financ. 1998, 22, 613-673. [CrossRef]

38. Cassar, G.; Ittner, C.D.; Cavalluzzo, K.S. Alternative information sources and information asymmetry reduction: Evidence from small business debt. J. Account. Econ. 2015, 59, 242-263. [CrossRef]

39. Luypaert, M.; Van Caneghem, T.; Van Uytbergen, S. Financial statement filing lags: An empirical analysis among small firms. Int. Small Bus. J. 2016, 34, 506-531. [CrossRef]

40. Niemi, L.; Sundgren, S. Are modified audit opinions related to the availability of credit? Evidence from Finnish SMEs. Eur. Account. Rev. 2012, 21, 767-796. [CrossRef]

41. Collis, J.; Jarvis, R.; Page, M. SMEs, Financial Reporting and Trade Credit: An International Study; Certified Accountants Educational Trust: London, UK, 2013.

42. Elemes, A.; Filip, A. Financial Reporting Quality and Private Firms' Access to Trade Credit Capital. Int. J. Account. 2021, Forthcoming.

43. Ceustermans, S.; Breesch, D.; Branson, J. Voluntary Disclosure of Sales and the Extent of Trade Credit in Small Private Companies. Account. Eur. 2017, 14, 388-406. [CrossRef]

44. Chen, D.; Liu, M.; Ma, T.; Martin, X. Accounting quality and trade credit. Account. Horiz. 2017, 31, 69-83. [CrossRef]

45. Petersen, M.A.; Rajan, R.G. The benefits of lending relationships: Evidence from small business data. J. Financ. 1994, 49, 3-37. [CrossRef]

46. Aaronson, R.W.; Bostic, P.; Huck, R. Townsend Supplier relationships and small business use of trade credit. J. Urban Econ. 2004, 55, 46-67. [CrossRef]

47. Ng, C.K.; Smith, J.K.; Smith, R.L. Evidence on the determinants of credit terms used in interfirm trade. J. Financ. 1999, 54, 1109-1129. [CrossRef]

48. Zager, K.; Decman, N. Guidelines and recommendations for improving the micro entities model of financial reporting. Procedia Econ. Financ. 2016, 39, 451-457. [CrossRef]

49. Jorissen, A. The role and current status of IFRS in the completion of national accounting rules-Evidence from Belgium. Account. Eur. 2017, 14, 29-39. [CrossRef]

50. Shipman, J.E.; Swanquist, Q.T.; Whited, R.L. Propensity score matching in accounting research. Account. Rev. 2017, 92, 213-244. [CrossRef]

51. Altman, E.I.; Iwanicz-Drozdowska, M.; Laitinen, E.K.; Suvas, A. Financial distress prediction in an international context: A review and empirical analysis of Altman's Z-score model. J. Int. Financ. Manag. Account. 2017, 28, 131-171. [CrossRef]

52. Andrieu, G.; Staglianò, R.; Van Der Zwan, P. Bank debt and trade credit for SMEs in Europe: Firm-, industry--, and country-level determinants. Small Bus. Econ. 2018, 51, 245-264. [CrossRef]

53. García-Teruel, P.J.; Martínez-Solano, P. Effects of working capital management on SME profitability. Int. J. Manag. Financ. 2007, 3, 164-177. [CrossRef]

54. Deloof, M.; La Rocca, M. Local financial development and the trade credit policy of Italian SMEs. Small Bus. Econ. 2015, 44, 905-924. [CrossRef]

55. Daoud, J.I. Multicollinearity and regression analysis. In Proceedings of the 4th International Conference on Mathematical Applications in Engineering 2017 (ICMAE'17), Kuala Lumpur, Malaysia, 8-9 August 2017; IOP Publishing: Bristol, UK, 2017; Volume 949, p. 012009. 